\title{
Production and Potential Income for Business of Oil Palm Empty Fruits Bunch as A Media for Growing Oyster Mushroom
}

\author{
Ni Kadek Sukriasih ${ }^{1}$, Ikawati Karim ${ }^{1 *}$, Suryani Dewi ${ }^{1}$, Makmur ${ }^{1}$ \\ Cengiz Kayacilar ${ }^{2}$ \\ ${ }^{1}$ Agribusiness Department, Universitas Sulawesi Barat Majene, West Sulawesi, Indonesia. \\ ${ }^{2}$ Niğde Ömer Halisdemir University, Turkey. \\ ${ }^{*}$ Corresponding author: \\ Email: ikawati@unsulbar.ac.id
}

\begin{abstract}
.
Solid waste produced by oil palm mills consists of oil palm empty bunches, shells, fibers and sludge. Oil palm empty fruit bunches contain 40 percent of cellulose, 24 percent of hemicellulose, 21 percent of lignin, and 15 percent of ash. This study aims to determine the production and the income potential of oyster mushrooms by using oil palm empty fruit bunches as a growth medium. This research is a quantitative descriptive study using an experimental design approach. Analysis of variance showed that all treatments had no significant effect on the length of mycelium fulfillment, the length of the mushroom stalk, the diameter of the fruit cap and the wet weight of the fungus. Treatment with KO without empty fruit bunches of oil palm has the same growth and production potential as treatment of K1-K4 using oil palm empty fruit bunches. Fungal growth and production are influenced by environmental, nutritional and genetic factors. The potential production of oyster mushrooms with wood sawdust and 15 baglog empty fruit bunches growing media is 5.2 kilograms with a total cost of IDR 297,250. The total revenue for twice harvests for each baglog is IDR 312,000. Therefore, to support the potential for growth and production of oyster mushrooms, oil palm empty fruit bunches can be used as a medium for growing oyster mushrooms because they have the potential for income to be used as a business.
\end{abstract}

Keywords: Oil palm empty fruit bunches, oyster mushroom, production, income

\section{INTRODUCTION}

Oyster mushroom is one of the horticultural products, and continues to be a favorite for vegetable lovers and vegetarians. The demand for mushrooms continues to increase and business actors respond by seriously opening up mushroom cultivation centers. Based on vegetable production in Indonesia, from 2015 to 2019 mushroom vegetable production fluctuated. In 2015, mushroom production increased by $3,348,464$ tons but in 2016 production decreased by 40,914 tons. In 2017 , production decreased by 37,020 tons and in 2018 , mushroom production greatly decreased as well by 31,052 tons. In 2019 mushroom production slightly increased by 33,163 tons, with the last growth in 2018 - 2019 of 6.80 percent [1]. Generally, the media that using for growing oyster mushrooms are wood sawdust, agricultural lime, and rice bran. The use 
of sawdust in the future is a concern when wood sawdust is difficult to obtain due to the currently reduced and limited forest potential. Wood sawdust is often also used in the manufacture of activated charcoal, charcoal bonds, and making bricks [2]. Another alternative for growing oyster mushroom plants is oil palm empty fruit bunches. It is an alternative and cheap substract for edible mushroom cultivation [3, 4]. The high content of cellulose and low content of lignin allows oil palm empty fruit bunch to be used as a media for growing oyster mushrooms [5].

Oil palm in West Sulawesi contributed highly to the farmers' income [6]. Crude oil palm as an export product is the main source for income of farmers for some districts in West Sulawesi [7]. Based on data from the Central Statistics Agency, 2018, there are three districts in West Sulawesi province that contribute to regional income through the oil palm plantation sector. Mamuju Regency produced 12,822 tons of oil palm, Pasangkayu Regency produced 142,976 tons, Central Mamuju Regency produced 106,003 tons. So that the total production of oil palm plantations in West Sulawesi is 261,801 tons [8]. In processing one ton of fresh fruit bunches of oil palm will produce as much as 23 percent or as much as 230 kilograms.One of the phenomena that occurs among farmers and in oil palm mills is the disposal and burning of empty oil palm bunches. Among farmers, oil palm empty fruit bunches are only piled under oil palm trees and sometimes farmers burn them directly. It is because they do not know that there is an economic value if empty oil palm fruit bunches are used optimally. This study aims to provide a solution to the utilization of oil palm empty fruit bunches that have not been managed and to determine the growth potential and income by adding oil palm empty fruit bunches as a medium for growing oyster mushrooms.

\section{METHODS}

This research was conducted in 2020 in one of the districts in West Sulawesi, namely Mamuju Regency. The type of research is quantitative research through an experimental design approach. The tools used in this study were a mushroom house, wooden racks, sieves, tarpaulins, large and small basins, pans, scales, machetes, thermometers, rulers, and writing utensils. While the tools used were oil palm empty fruit bunches, F2 oyster mushroom seeds, bran, agricultural lime, sawdust, clean water, spirit, bunsen, rubber bands, newsprint, bamboo rings, and sugar plastic. The working procedures in this research are: making kumbung and planting racks. media manufacture, composting, media packaging, sterilization, mushroom seed inoculation, incubation, maintenance, and harvesting.

The analytical technique used in this study was a completely randomized design through which treatments were given randomly to all experimental units. The experimental design can be carried out because the environment where the experiment is relatively homogeneous so that the media or experimental site did not have a 
significant influence on the observed response. The general mathematical model for a completely randomized design is as follows:

$$
\mathrm{x}=\mu+\mathrm{Ti}+\sum \mathrm{ij}
$$

After that, an analysis of the calculation of the potential income from the production is carried out through randomized design experiments that have been carried out. Income analysis can be known by first determining the total cost of production consisting of fixed and variable costs. The formula used to calculate the cost is as follows:

$$
\mathrm{TC}=\mathrm{FC}+\mathrm{VC}
$$

Description:

$\mathrm{TC}=$ Total Cost (IDR)

$\mathrm{FC} \quad=$ Fixed Cost (IDR)

$\mathrm{VC}=$ Variabel Cost (IDR)

After calculating the total costs incurred, then calculating the total revenue which can be calculated by multiplying the production obtained by the estimated selling price. Total revenue is also named with gross output from multiplying of the total production in a hectare with the selling price of product [9]. The formula used is as follows:

$$
\mathrm{TR}=\mathrm{P} \times \mathrm{Q}
$$

Description:

$$
\begin{array}{ll}
\mathrm{TR} & =\text { Total Revenue (IDR) } \\
\mathrm{P} & =\text { Price (IDR/Kilogram) } \\
\mathrm{Q} & =\text { Quantity (Kilogram) }
\end{array}
$$

From calculating the total costs and total revenue, it can be seen that the income obtained in this study, the income formula can be written as follows:

$$
\pi=\mathrm{TR}-\mathrm{TC} \text {. }
$$

Description:

$$
\begin{array}{ll}
\pi & =\text { Income (IDR) } \\
\mathrm{TR} & =\text { Total Revenue (IDR) } \\
\mathrm{TC} & =\text { Total Cost (IDR) }
\end{array}
$$

\section{RESULT AND DISCUSSION}

\subsection{Oyster Mushroom Growth Components}

The growth of oyster mushrooms is an increase in size both in terms of volume, weight, number of cells or the number of protoplasm that cannot return to its origin. The growth of oyster mushrooms is also a refinement of the structure and function of organs that accompany the growth process [10]. From the average calculation of the growth components of oyster mushrooms, the parameters observed were mycelium growth, oyster mushroom wet weight, mushroom stalk length, and mushroom cap diameter from all treatments K0 - K4 showed no significant difference. Meanwhile, from the calculation of the results of the analysis of variance, all 
treatments did not have a significant effect on the length of mycelium fulfillment, mushroom stalk length, growth and wet weight of the fungus. The micellium was growing differently for each baglog based on the mushroom growth [3]. Treatment with K1 without oil palm empty fruit bunches had the same growth and production potential as treatment with $\mathrm{K} 1-\mathrm{K} 4$ using oil palm empty fruit bunch. The growth and production of fungi are influenced by environmental factors, utritional factors and genetic factors.

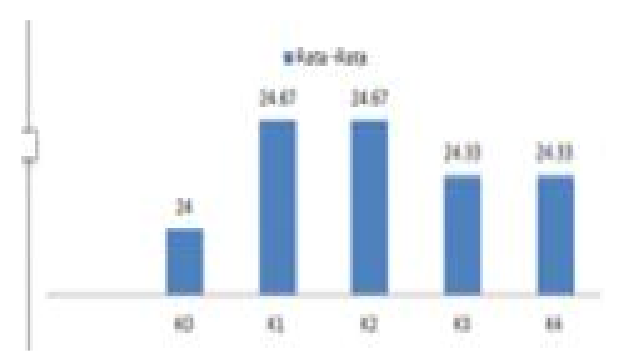

a. Mycelium fulfillment

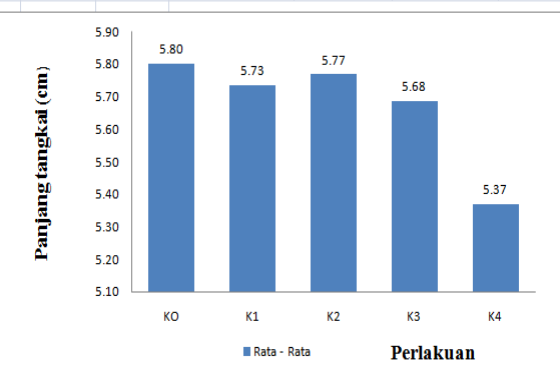

c. Mushroom stalk length

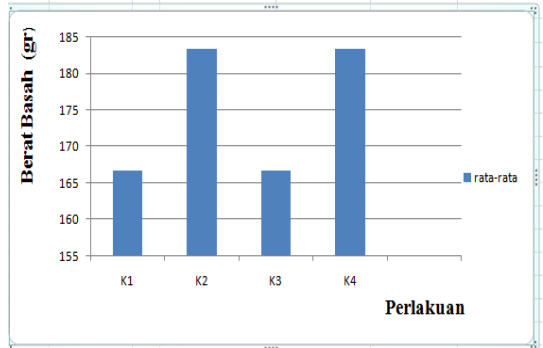

b. Mushroom wet weight

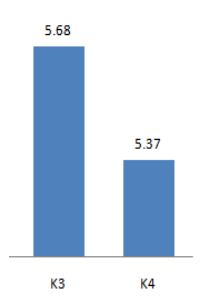

Perlakuan

d. Mushroom hood diameter

Fig 1. Calculation of the average value of oyster mushroom growth components (a) mycelium fulfillment, (b) mushroom wet weight, (c) mushroom stalk length, (d) mushroom hood diameter

Oyster mushroom fruit growth factors are strongly influenced by two factors; environmental and nutritional factors [11]. Environmental factors in the form of radiation intensity, temperature, acidity, and humidity. Oyster mushroom body growth requires nitrogen, carbon, and carbohydrates. In addition, it requires elements of phosphorus, protein, calcium, oxygen and vitamins. The more nutrients that are absorbed, the more fruit will grow. The growth and development of oyster mushrooms are influenced by genetic factors, growing media, and environmental factors.

\subsection{Total Revenue, Total Cost, and Income}

\section{- Total Revenue}

Total revenue of each treatment in 2 times the production of each baglog on average is able to produce oyster mushrooms as much as $0.1-0.2$ kilograms. Which in the $\mathrm{K} 0$ treatment with the addition of 5 kilograms of sawdust media +0 kilograms of empty oil palm fruit bunches +0.75 kilograms of bran +0.1 kilograms of lime resulted 
in a wet weight of 1 kilograms of mushrooms. K1 treatment with the addition of 0 kilograms sawdust +5 kilograms empty palm oil bunches +0.75 kilograms bran +0.1 kilograms lime resulted in a wet weight of 1 kilograms of mushrooms. K2 treatment with the addition of 2.5 kilograms sawdust +2.5 kilograms oil palm empty bunches + 0.75 kilograms bran +0.1 kilograms lime resulted in a wet weight of 1.1 kilograms. K3 treatment with the addition of 1.25 kilograms of sawdust +3.75 kilograms of palm cosone bunches +0.75 kilograms of bran +0.1 kilograms of lime resulted in a wet weight of 1 kilograms of mushrooms.

K4 treatment with the addition of 0.4 kilograms of sawdust +4.25 kilograms of oil palm empty fruit bunches +0.75 kilograms of bran +0.1 kilograms of lime resulted in a wet weight of 1.1 kilograms of mushrooms. So, the total wet weight of mushrooms from K0 - K4 treatment is 5.2 kilograms. Revenue for each treatment where every 5 treatments there are 3 replications so that it becomes 15 baglogs in 2 times of production. Revenue can be calculated by the selling price (IDR) multiplied by the total of production units (kilograms). Revenue in treatment K0 is IDR 60,000, treatment $\mathrm{K} 1$ is IDR 60,000 , the $\mathrm{K} 2$ treatment received IDR 66,000, the K3 treatment received IDR 60,000, and the K4 treatment received IDR 66,000. then the total revenue from 15 baglogs in 2 times of production is IDR 312,000.

\section{- Total Cost}

Cost absorbs all the expenses of production which is used [12]. It consists of fixed costs and variable costs. Fixed costs incurred by calculating the depreciation cost of the tools used. The depreciation cost for tools such as scales is IDR 75,000, the tarpaulin depreciation expense is IDR 15,000, the depretiation cost of pan is IDR 15,000 , the depreciation cost of the machete is IDR 5,000, the depreciation cost of the thermometer is IDR 4,250, and the sprayer depreciation cost is IDR 6,000. Then, the total of fixed costs incurred to produce oyster mushrooms is IDR 120,250.The next step is calculating of variable costs. These costs changed in proportion to the quantity of output [13] or volume associated with these variable costs. The variable costs incurred include the cost of production facilities consisting of seed, plastic, spritus, bran, agricultural lime, rubber band, nail, and shipping for mushroom seed packages and thermometers.

\section{Seed cost}

The number of oyster mushroom seeds used is 2 packs. The price of one packet of mushroom seeds is IDR 5,000. So that, the total cost incurred for the purchase of oyster mushroom seeds is IDR 10,000. The mushroom seeds used were F2 oyster mushroom seeds. The type of florida in STP plastic is packaging, where the contents were more than sauce bottles using pure corn as a medium.

\section{Plastic cost}

The plastic used is polypropylene $(\mathrm{PP})$ plastic with a size of $18 \times 30$ centimeters, one roll of plastic is used at a price of IDR 9,000. So that the costs incurred for the purchase of plastic is only IDR 9,000. 


\section{Spritus cost}

The total of use of spritus is one bottle with a price of IDR 10,000 per bottle. So, the number of spritus costs incurred is IDR 10,000.

\section{4. bran cost}

The amount of bran used is 5 kilograms at a price of IDR 3,000 per $\mathrm{kg}$, so the total cost incurred for the purchase of bran is IDR 15,000 .

\section{Agricultural lime cost}

The amount of lime used is $2 \mathrm{~kg}$ at a price of IDR 2,500 per $\mathrm{kg}$, so the total cost incurred for the purchase of lime is IDR 5,000.

\section{Rubber band cost}

The Total of use of rubber bands is one pack at a price of IDR 6,000 per pack, so the total costs incurred for the purchase of rubber bands are IDR 6,000 .

\section{Nail cost}

The number of nails used is as much as $1 / 4 \mathrm{~kg}$ at a price of IDR 20,000 per $\mathrm{kg}$, so the total cost incurred for the purchase of nails is IDR 5,000.

\section{Shipping costs for mushroom seed packages and thermometers}

Delivery of oyster mushroom seeds in two packs weighing $1 \mathrm{~kg}$ at a price of IDR 58,500. Meanwhile, the delivery of the 1 set thermometer package was IDR 58,500 . Based on the results of the translation of the variable costs above for the cost of production facilities, the total variable costs incurred are IDR 177,000.Based on the total of production costs, in this case variable costs and fixed costs, so that the total production cost of oyster mushrooms is IDR 297,250.

\section{- Income}

Income or net income is the profit earned, where the results are obtained from the reduction between total revenues and total costs. Therefore, the income obtained from the oyster mushroom business potential is about IDR 14,750. In the future, if oyster mushrooms are produced in large quantities, the profits to be obtained will be even more. Through the support of technology, the use of empty fruit bunch as a media for oyster mushroom has been increasingly developed. Oyster mushroom cultivation had a great potential in Indonesia because it only produced $10,000-12,500$ tonnes/year while the market demand reached 21,900 tonnes/year [3].

\section{CONCLUSION}

The conclusions in this study are as follows:

[1] From the results of analysis of variance, all treatments did not have a significant effect on the length of mycelium fulfillment, mushroom stalk length, growth and wet weight of the fungus. treatment with $\mathrm{K} 1$ without oil palm empty fruit bunches had the same growth and production potential as treatment K1-K4. The growth and production of fungi are influenced by environmental, nutritional, and genetic factors. 
[2] Potential production of oyster mushrooms with wood sawdust and oil palm empty fruit bunches growing media of 15 baglogs from 2 times of production is 5.2 kilograms, the total cost is IDR 297,250 where the revenue for two harvests for each baglog is IDR 312,000. So that, the income for oyster mushroom business potential is about IDR 14,750 .

\section{REFERENCES}

[1] Statistik Badan Direktorat Jendral Hortikultura .2015. 3-Produksi Nasional Sayuran.Pdf.

[2] Sukmawati, Fitria Nugraheni, Pradita Risky Goldina, 2018. Pemanfaatan Tandan Kosong Kelapa Sawit Sebagai Media Jamur Tiram (Pleourotus osteratus). Gontor AGROTECH Science Journal. 4(2) 139 - 153.

[3] Marlina, Lin., Sukotjo, Setiardi, Marsudi Sidik. 2015. Potential of Oil Palm Empty Fruit Bunch (EFB) as Media for Oyster Mushroom, Pleurotus ostreatus Cultivation. International Symposium on Applied Chemistry 2015 (ISAC 2015), Procedia Chemistry 16 (2015) 427-431.

[4] Kavitha, B., Rajannan G and Jothimani, P. 2013. Utilization of Empty Fruit Bunch of Oil Palm as Alternative Substrate for The Cultivation of Mushroom. International Journal of Science, Environment, and Technology, Vol 2, No.5. 2013, 839-846.

[5] Razak, Dang Lelamurni Binti Abd. Cultivation of Auricularia polytricha Mont. Sacc. (black Jelly Mushroom) Using Oil Palm Waste. Thesis Faculty of Science Universiy of Malaya, Kuala Lumpur.

[6] Astuti, N S., Makmur., Karim, I., Nurlaela., Abdullah, M A., and Dahniar. 2020. Contribution of Oil Palm (Elaeis guineensis J.) Plantation to Farmers' Income in West Sulawesi. Anjoro: International Journal of Agriculture and Business, Vol 1 Issue 2, September, 2020.

[7] Hajrah, S., Makmur., Fatmawaty, D., and Karim, I. The Effect of Purchase Price of Oil Palm Fresh Fruit Bunches (FFB) on Fetilization Frequency (Case Study: Mamuju Regency, West Sulawesi). Anjoro: International Journal of Agriculture and Business, Vol 2 Issue 1, May, 2021.

[8] Badan Pusat Statistik Provinsi Sulawesi Barat. 2018. Produksi Tanaman Perkebunan Menurut Kabupaten Dan Jenis Tanaman Di Sulawesi Barat (Ton), 2018.

[9] Karim, I., Makmur., and Bahmid, N A. 2018. Pearl Millet (Pennisetum glaucum) farming for food security: Gross output, net farm income, and B/C ratio. IOP Conf. Series: Earth and Environmental Science 235 (2019) 012044.

[10] Fatmawati. 2017. Pertumbuhan Jamur Tiram Putih ( Pleurotus Ostreatus) Pada Berbagai Komposisi Media Tanam Serbuk Gergaji Kayu Dan Serbuk Sabut Kelapa (Cocopeat). Skripsi. Fakultas SAINS Dan Teknologi. UIN Alauddin Makassar.

[11] Suhaeni, S., Yunus, N. M., Nurjannah, S., \& Sari, A.2018. Pertumbuhan dan Produktivitas Jamur Tiram Puth (Pleurotus ostreatus) pada Media Tanam Sabut Kelapa Sawit (Elaeis guinensis) dan Kulit Durian (Durio zibethinus). In Prosiding Seminar Nasional Biologi (Vol. 4, No. 1). 
[12] Sorin Briciu, 2008. "Variable And Fixed Costs In Company Management," Annales Universitatis Apulensis Series Oeconomica, Faculty of Sciences, "1 Decembrie 1918" University, Alba Iulia, vol. 1(10), pages 1-14.

[13] (2000) Variable Costs. In: Swamidass P.M. (eds) Encyclopedia of Production and Manufacturing Management. Springer, Boston, MA . https://doi.org/10.1007/14020-0612-8_1033 